\title{
THE ALBERTA LAND STEWARDSHIP ACT AND ITS IMPACT ON ALBERTA'S OIL AND GAS INDUSTRY
}

\author{
Alan HARVIE* AND TRENT MERCIER **
}

This article discusses the impact of the Alberta Land Stewardship Act - enacted by the Government of Alberta with the goal of developing an overarching land use policy to manage all lands and natural resources in the province - on Albertans generally, as well as the oil, gas, and oil sands industries. Although the implementation of the Act is in its early stages, the article nonetheless argues that the Act, and the authority that it grants, will significantly alter the way that land use decisions are made in Alberta and, of specific interest to those in the oil, gas, and oil sands industries, the manner in which proposed projects are reviewed and approved.
Cet article porte sur l'impact de la Alberta Land Stewardship Act ou loi sur la gestion des terres de l'Alberta, adoptée par le gouvernement provincial dans le but de développer une politique très importante sur l'utilisation des terres pour gérer l'ensemble des terres et des ressources naturelles de la province pour les Albertains en général, mais aussi pour le secteur pétrolier, gazier et celui des sables bitumineux. Bien que la mise en vigueur de la Loi en soit à ses débuts, l'article fait néanmoins valoir que la Loi et l'autorité qu'elle confère changeront considérablement la manière dont les décisions sur l'utilisation des terres sont prises en Alberta; la manière dont les projets sont examinés et approuvés touche tout spécialement le secteur pétrolier, gazier et celui des sables bitumineux.

\section{TABLE OF CONTENTS}

I. INTRODUCTION . . . . . . . . . . . . . . . . . . . . . . . . . . 296

II. BACKGROUND . . . . . . . . . . . . . . . . . . . . . . . . . . . . . . . . . . . 297

A. The History of LAND Management in Alberta . . . . . . . . . 297

B. THE LAND-USE FRAMEWORK . . . . . . . . . . . . . . . . . . . . . . . . 298

III. THE ALBERTA LAND STEWARDSHIP ACT . . . . . . . . . . . . . . . . . . . . 302

A. THE SCOPE AND APPLICATION OF THE

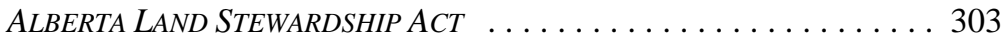

B. Planning Regions and Regional Plans $\ldots \ldots \ldots \ldots \ldots$

C. The Nature and Effect of Regional Plans $\ldots \ldots \ldots$. . . . . . . 307

D. THE LAND-USE SECRETARIAT

AND THE REGIONAL ADVISORY COUNCILS . . . . . . . . . . . . . . 308

E. ReVIeWing ANd Amending a Regional Plan . . . . . . . . . . . . . 309

F. The Compliance Review and Appeal Process . . . . . . . . . 309

G. CONSERVATION AND STEWARDSHIP TOOLS . . . . . . . . . . . 310

IV. IMPLEMENTATION OF THE

ALBERTA LAND STEWARDSHIP ACT . . . . . . . . . . . . . . . . . . 315

A. The Lower Athabasca Regional Plan . . . . . . . . . . . . 315

B. The South Saskatchewan Regional Plan . . . . . . . . . . . 318

C. Transitional Provisions . . . . . . . . . . . . . . 319

V. AMENDing AND Extinguishing Rights $\ldots \ldots \ldots \ldots \ldots \ldots \ldots \ldots$

A. COMPENSATION FOR LOSS OF VALUE

OR USE OF LAND . . . . . . . . . . . . . . . . . . . . . . . 321

* $\quad$ Partner, Macleod Dixon LLP, Calgary, Alberta.

*** Associate, Macleod Dixon LLP, Calgary, Alberta. The authors wish to extend a special thanks to Colleen

T. Stevenson and Fraser Bush for their assistance with the preparation of this article. 
VI. HOW THE ALBERTA LAND STEWARDSHIP ACT MAY CHANGE

THE Mineral AcQuisition Process . . . . . . . . . . . . . . . . . . 325

A. FREEHOLD DisPOSITIONS . . . . . . . . . . . . . . . . . . . . . 325

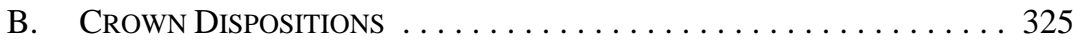

VII. HOW THE ALBERTA LAND STEWARDSHIP ACT MAY CHANGE

REgULATORY APPROVALS . . . . . . . . . . . . . . . . . . . . . . 326

A. The EnERgy Resources Conservation BoARD . . . . . . . . . 326

B. Alberta ENVIRONMENT . . . . . . . . . . . . . . . . 329

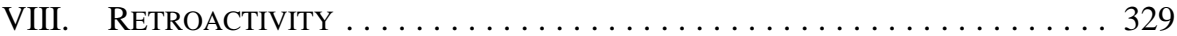

IX. CONCLUSION ........................... 330

\section{INTRODUCTION}

The record population and economic growth that Alberta has experienced has been well documented. The population of Alberta has grown at more than double the Canadian rate ${ }^{1}$ and now stands at over 3.5 million people, compared with a population of only 2.7 million people less than 15 years ago. ${ }^{2}$ Alberta's main economic drivers are the oil, gas, and oil sands industries, now consistently representing over half the dollars invested in the province. ${ }^{3}$ This growth, however, has not been without its problems. Its pace and scope have increased conflicts between competing land users, including industrial, agricultural, residential, and recreational users, Aboriginal communities, and environmental groups. To address this situation, in 2005 the Government of Alberta launched an initiative to develop an overarching land use policy to manage public and private lands and natural resources in the province.

After three years of stakeholder and public consultations, the government's blueprint for a new land use policy, known as the Land-use Framework, was released. ${ }^{4}$ The stated objective of the Framework is to develop an outcome based land use decision-making process that promotes sustainable economic growth by balancing economic activities with social and environmental goals. ${ }^{5}$ The Framework outlines seven land use strategies and identifies several priority action items and key issues that the government must address.

In the spring of 2009, Bill 36, the Alberta Land Stewardship Act, ${ }^{6}$ was introduced. It received royal assent on 4 June 2009 and was largely proclaimed in force on 1 Office of Statistics and Information <https://osi.alberta.ca/osi-content/Pages/Factsheets/Population GrowthinAlbertaandCanada.aspx>.

2 Government of Canada, "Population urban and rural, by province and territory (Alberta)," online: Statistics Canada <http://www40.statcan.ca/101/cst01/demo62j-eng.htm>.

3 Robert L. Mansell \& Ron Schlenker, Energy and the Alberta Economy: Past and Future Impacts and Implications, Paper No. 1 of the Alberta Energy Futures Project (Calgary: Institute of Sustainable Energy, Environment and Economy, University of Calgary, 2006) at 10.

4 Government of Alberta, Land-use Framework (Edmonton: Alberta Sustainable Resource Development, 2008), online: Alberta Sustainable Resource Development < http://www.landuse.alberta.ca/documents/ Final_Land_use_Framework.pdf $>$ [Framework].

$5 \quad$ Ibid. at 2.

$6 \quad$ S.A. 2009 , c. A-26.8 [ALSA]. 
October 2009. ${ }^{7}$ ALSA provides the legislative framework and legal authority for implementation of the Framework.

Since ALSA is still in the early stages of implementation, it is not yet possible to discuss in detail the impacts that it will have on Alberta's oil, gas, and oil sands industries. However, ALSA's framework, and the authority it grants, suggests that significant changes will occur in the way land use decisions are made and the manner in which proposed projects are reviewed and approved. The purpose of this article is to examine both the Framework and ALSA and consider how they may impact Albertans generally, and specifically how they are likely to impact the province's oil, gas, and oil sands industries. ${ }^{8}$

\section{BACKGROUND}

\section{A. The History OF LAND MANAgEMENT in Alberta}

The Framework is not Alberta's first land use management strategy. The government has been developing and implementing land management practices in Alberta for more than 60 years. In 1948, the government divided Alberta into two areas for the purpose of managing public lands. Public lands in the Green Area were to be initially managed primarily for timber production, watershed and wildlife habitat protection, and recreation. Public lands in the White Area were initially designated for settlement and agriculture. ${ }^{9}$ Although the primary uses for the Green and White Areas have expanded, land management decisions continue to be made in accordance with these boundaries.

Over the years, the government has developed a vast array of policies, strategies, and initiatives for managing lands and competing land uses such as A Policy for Resources Management of the Eastern Slopes, the Integrated Resource Plans, the Alberta Forest Conservation Strategy, Special Places 2000: Alberta's Natural Heritage, and the Regional Sustainable Development Strategy for the Athabasca Oil Sands Area. ${ }^{10}$ Management strategies for air and water resources also exist and include Water for Life: Alberta's Strategy for Sustainability, the Clean Air Strategy for Alberta, and, most recently, Alberta's 2008

\section{April 2010.}

All of its sections came into force on 1 October 2009 except ss. 77 and 91, which came into force on 1

Federal land comprises approximately 10 percent of the total land base in Alberta, and includes national parks, Indian Reserves, and military bases and installations. This article does not discuss the interplay between provincial and federal approval in respect of land use activities on federal lands within Alberta. Framework, supra note 4 at 6.

10 Government of Alberta, A Policy for Resource Management of the Eastern Slopes (Calgary: Alberta Energy, 1984), online: Alberta Sustainable Resource Development <http://www.srd.alberta.ca/ ManagingPrograms/Lands/Planning/documents/IntegratedResourcePlan-APolicyforResource Management-EasternSlopes-1984.pdf>; Government of Alberta, "Integrated Resource Plans,” online: Alberta Sustainable Resource Development <http://www.srd.alberta.ca/ManagingPrograms/Lands/ Planning/IntegratedResourcePlans.aspx>; Government of Alberta, Special Places 2000: Alberta's Natural Heritage (Policy and Implementation Plan) (Edmonton: Alberta Environmental Protection, 1995) [Special Places 2000]; Government of Alberta, Alberta Forest Conservation Strategy: A New Perspective on Sustaining Alberta's Forests (N.p.: Canada-Alberta Partnership Agreement in Forestry, 1997); Government of Alberta, Regional Sustainable Development Strategy for the Athabasca Oil Sands Area (Calgary: Alberta Environment, 1999), online: Legislative Assembly of Alberta <http:// www.assembly.ab.ca/lao/library/egovdocs/alen/1999/69092.pdf > . 
Climate Change Strategy. ${ }^{11}$ Nonetheless, the Framework is unique in that is a comprehensive approach that applies to both public and private lands. Further, by giving this approach the force of law and by integrating various existing management strategies, Alberta has signalled that it is embarking on a novel and unprecedented approach to land management.

\section{B. THE LAND-USE FRAMEWORK}

ALSA is the legal instrument for implementing the land management strategies of the Framework. In order to properly consider ALSA, and what the government is attempting to achieve through this legislation, it is necessary to first review the components of the Framework.

The Framework is a combination of the experiences gained from previous provincial land management approaches, the input from an extensive public consultation process, and the results of the government's analysis of land management in 12 other jurisdictions, including five Canadian provinces, six U.S. states, and Australia. ${ }^{12}$ The government's vision and objectives for the future of Alberta's land management process is articulated in the Framework through the identification of seven key strategies and a number of priority action items. ${ }^{13}$ The following is a review of each of these strategies and items.

\section{LAND USE REGIONS AND REGIONAL PLANS}

Recognizing that land management policies need to look beyond a project-by-project analysis, the first strategy of the Framework is the creation of a region based land use planning system, which divides the province into seven regions and requires that all land use decisions are based on regional considerations. The Framework contemplates that a regional plan will be developed for each region by 2012 to serve as a guide as to how land use activities should be carried out. It proposes that each regional plan will summarize the current state of the region, identify present and future key issues and trends, describe a vision for the region consistent with the principles established in the Framework, and articulate strategies, actions, and approaches that should be followed to ensure that the region is developed in a manner that achieves the broad vision and objectives of the Framework while addressing the unique economic, social, and environmental issues facing the region. ${ }^{14}$ The

11 Government of Alberta, Water for Life: Alberta's Strategy for Sustainability (Calgary: Alberta Environment, 2003), online: Government of Alberta <http://www.waterforlife.alberta.ca/documents/wflstrategy_Nov2003.pdf> [Water for Life]; Government of Alberta, Clean Air Strategy for Alberta (Edmonton: Clean Air Strategy for Alberta, 1991), online: Clean Air Strategic Alliance <http://www. casahome.org/wp-content/uploads/2009/10/Clean-Air-Strategy-for-Alberta-Report-to-Ministers1991.PDF> [Clean Air Strategy]; Government of Alberta, Alberta's 2008 Climate Change Strategy: Responsibility/Leadership/Action (Calgary: Alberta Environment, 2008), online: Alberta Environment $<$ http://environment.gov.ab.ca/info/library/7894.pdf > [Climate Change Strategy].

12 UMA/AECOM Engineering Ltd., Alberta Land Use Framework: Jurisdictional Review of Land Use and Land Management Policy - Final Report (Calgary: UMA/AECOM Engineering, 2007) at 1, online: Alberta Sustainable Resource Development < http://www.landuse.alberta.ca/AboutLanduse Framework/ LUFProgress/documents/JurisdictionalReviewOfLanduseLandManagementPolicy-Final-Oct2007.pdf>.

13 See Framework, supra note 4 at 19-21, for a review of the seven strategies. (Edmonton: Alberta Sustainable Resource Development, 2009) at 4-5, online: Alberta Sustainable Resource Development <http://www.landuse.alberta.ca/RegionalPlans/LowerAthabasca/documents/ TermsOfRefDevLowerAthabascaRegionalPlan-Jul2009.pdf $>$ [Athabasca Terms of Reference]. 
regional plans are to be based on a planning horizon of at least 50 years and may include subregional or issue-specific plans to address specific land use issues in the region. ${ }^{15}$

The seven planning regions are: the South Saskatchewan, the North Saskatchewan, the Upper Peace, the Lower Peace, the Upper Athabasca, the Lower Athabasca, and the Red Deer. The regions are not based on political boundaries, but rather reflect the province's major watersheds. The Red Deer and South Saskatchewan regions are both in the South Saskatchewan River watershed. However, due to unique pressures facing the northern and southern portions of the watershed, separate planning regions were established. ${ }^{16}$

\section{THE LAND-USE SECRETARIAT AND THE REgIONAL AdVISORY COUNCILS}

Land use decisions in the province are frequently criticized as being fragmented and made along the "narrow mandates" and "organizational cultures" of the province's various decision-making bodies. ${ }^{17}$ The second strategy in the Framework addresses this criticism by calling for a new bureaucracy within the public service, independent of any existing ministry, to be known as the Land-use Secretariat (Secretariat). The Secretariat will take responsibility for the Framework by overseeing the development and implementation of the seven regional plans. ${ }^{18}$ The Framework further contemplates the creation of a Regional Advisory Council (RAC) for each planning region with a mandate to provide advice to the Secretariat on what the region should look like over the long-term and how activities in the region should be planned. Each RAC will also advise the Secretariat during the preparation of their region's regional plan. The RACs are intended to be comprised of persons with experience and expertise in the region who represent a variety of perspectives, including those of the provincial and municipal governments, other relevant planning bodies, Aboriginal communities, industry, and non-governmental organizations. Each RAC will have technical and research support from a regional planning team staffed by senior government personnel and regulatory authorities that will be responsible for implementing and administering the regional plan. ${ }^{19}$

The government is to provide each RAC with terms of reference setting out the government's economic, environmental, and social expectations for their region and the policies and objectives that are to be included in the regional plan. It is anticipated that the responsible RAC will provide advice and recommendations on, among others things:

- strategies to assist in achieving the goals and objectives of the Framework in the region over the long-term;

- $\quad$ environmental thresholds for land, air, water, and biodiversity in the region;

$15 \quad$ Ibid. at 3.

$16 \quad$ Framework, supra note 4 at 24.

17 Steven A. Kennett, The Law of the Land: A Legal Foundation for Alberta's Land-Use Framework (Drayton Valley: The Pembina Institute, 2009) at 2.2.1, online: The Pembina Institute <http://pubs. pembina.org/reports/law-of-the-land-report.pdf $>$.

$18 \quad$ Framework, supra note 4 at 29.

Ibid. 
- monitoring, evaluating, and assessing procedures for tracking the effectiveness of land use decisions in the region;

- $\quad$ reconciliation of competing land uses in the region; and

- $\quad$ methods to integrate existing government policies into the regional plan. ${ }^{20}$

It is anticipated that each RAC will consult with stakeholders and the key government departments that will play a role in the regulation of land use activities within their region. An important feature of this strategy is that neither the RACs nor the Secretariat have the authority to approve the regional plans. That authority is reserved for the Lieutenant Governor in Council. ${ }^{21}$

\section{Cumulative EFFECTS MANAGEMENT}

The Framework recognizes, and indeed emphasizes, the interrelationship between land (including biodiversity), air, and water resources, and acknowledges that these resources have a finite capacity. ${ }^{22}$ The third strategy anticipates that all future land use decisions in the province will be based on considerations of the past, current, and reasonably foreseeable future effects of a proposed activity. Although cumulative effects management has been part of official government policy for some time, it is largely perceived as only applying to decisions relating to major projects. Consequently, this strategy signals that there may be a change in how smaller oil and gas projects, such as the drilling of wells and the construction of tie-in pipelines, compressors, and minor facilities will be considered.

\section{CONSERVATION AND STEWARDSHIP STRATEGIES}

The conservation of important landscapes in the province has been a continuing initiative, as reflected in the province's provincial parks and protected areas legislation, Special Places $2000,{ }^{23}$ and the ability to create conservation easements under the Environmental Protection and Enhancement Act. ${ }^{24}$ Nonetheless, during the Framework consultation process, participants expressed a strong desire for the government to do a better job conserving land in the province, both by protecting land from further development and by encouraging land use activities that minimize environmental impacts. ${ }^{25}$ The Framework provides that these goals will be partially achieved through the regional plans. However, it anticipates that additional conservation and stewardship tools will need to be developed. ${ }^{26}$

\section{PROMOTE EFFICIENT USE OF LAND}

The fifth strategy of the Framework is related to the need to address the environmental impact arising from the increased economic activity in the province. It identifies the need to

Athabasca Terms of Reference, supra note 14 at 4-6.

Ibid. at 5.

Framework, supra note 4 at 2.

Supra note 10.

R.S.A. 2000, c. E-12 [EPEA].

Framework, supra note 4 at 8.

Ibid. at 43. 
encourage future land use activities that better share resources amongst competing users and have a reduced impact on the land. Industrial land users will be encouraged to apply an integrated land management approach to the design and implementation of their proposed projects. Some industries already implement such an approach in their project designs. For instance, private roads are commonly shared amongst competing oil and gas developers as well as with forestry companies. ${ }^{27}$ The Framework suggests that the government intends to take a more active role in facilitating these kinds of efficiencies. This strategy has the potential to significantly alter the manner in which oil and gas projects will be designed in the future.

\section{ESTABLISHING INFORMATION, MONITORING, AND KNOWLEDGE SYSTEMS}

The sixth strategy in the Framework is designed to increase collaboration and information sharing to support land use planning and to facilitate government monitoring and evaluation of land use decisions in order to ensure the achievement of the Framework's and the regional plans' policies and objectives. It is anticipated that existing initiatives, such as the Biodiversity Monitoring Program, and the improvement of information initiatives, such as the Alberta Conservation Information Management System, will be used to advance this strategy. ${ }^{28}$

\section{INCLUSION OF ABORIGINAL PEOPLES IN LAND USE PLANNING}

In preparing the Framework, the government emphasized the need to include First Nations and Métis organizations in the consultation process. ${ }^{29}$ These Aboriginal-specific consultations revealed that many Aboriginal peoples had concerns regarding the government's failure to meet its legal and constitutional consultation obligations with respect to development decisions potentially adverse to Aboriginal rights. ${ }^{30}$ In response to these concerns, the Framework emphasizes the government's intention to meaningfully engage Aboriginal communities in the province's new land management process. ${ }^{31}$

An example of this is the Al-Pac-Opti/Nexen integrated planning scenario profiled in the Government of Alberta's LUF Quarterly: Land-use Framework Progress Report (February 2010) at 8, online: Alberta Sustainable Resource Development < http://www.landuse.alberta.ca/documents/LUFQuarterlyFeb2010.pdf>.

The Biodiversity Monitoring Program is being implemented through the Alberta Biodiversity Monitoring Institute, online: Alberta Biodiversity Monitoring Institute <http://www.abmi.ca/abmi/ home/home.jsp>. For information on the Alberta Conservation Information Management System, see Government of Alberta, "Alberta Conservation Information Management System (Formerly ANHIC)," online: Alberta Tourism, Parks and Recreation <http://tpr.alberta.ca/parks/heritageinfocentre/default. aspx>.

29 See Government of Alberta, Land-use Framework: Response to Aboriginal Consultation on the Draft Alberta Land-use Framework 2008 (Edmonton: Alberta Sustainable Resource Development, 2008), online: Alberta Sustainable Resource Development $<$ http://www.landuse.alberta.ca/AboutLanduse Framework/LUFProgress/documents/ResponseAboriginalConsult-DraftLUF2008-Sep09.pdf $>$ [Response to Aboriginal Consultation]. 


\section{IMMEDIATE PRIORITIES AND POLICY GAPS TO BE ADDRESSED}

The Framework identifies five immediate priorities the government is to support or undertake: enact legislation to support the Framework, support the development of metropolitan plans for both the Capital and Calgary regions, and develop regional plans for the Lower Athabasca and South Saskatchewan regions. ${ }^{32}$ The government further commits in the Framework to addressing what it frames as significant "policy gaps" in the following areas: conflicts between surface and subsurface activities, fragmentation and conversion of agricultural land, establishment of transportation and utilities corridors, management of the recreational use of public lands, conservation and protection of the diversity of Alberta's ecological regions, and management of flood risks. ${ }^{33}$

Regional plans for the Lower Athabasca and South Saskatchewan regions are identified as priorities due to the significant pressures facing these regions. ${ }^{34}$ The Lower Athabasca region is home to most of the oil sands activity in the province; the economic, environmental, and social impacts of which make this region a priority. The South Saskatchewan region is a priority region due to its large population (45 percent of the province's population) and limited water resources, which may constrain future economic development. ${ }^{35}$

\section{THE ALBERTA LAND STEWARDSHIP ACT}

ALSA is primarily enabling legislation that creates a structure for the implementation of the Framework and grants the government authority to conduct actions and pass regulations as may be necessary to advance the purposes of the Framework. Consequently, it is important to understand the actions and regulations that may be taken and enacted in connection with this Act.

The purpose provision of $A L S A$ reiterates the general policies and objectives articulated in the Framework. Section 1 reads as follows:

Purposes of Act

1 The purposes of this Act are

(a) to provide a means by which the Government can give direction and provide leadership in identifying the objectives of the Province of Alberta, including economic, environmental and social objectives;

(b) to provide a means to plan for the future, recognizing the need to manage activity to meet the reasonably foreseeable needs of current and future generations of Albertans, including aboriginal peoples;

Framework, ibid. at 43-45.

Ibid. at $45-46$.

Ibid. at 44-45.

Government of Alberta, Terms of Reference For Developing the South Saskatchewan Region (Edmonton: Alberta Sustainable Resource Development, 2009) at 9, online: Alberta Sustainable Resource Development <http://www.landuse.alberta.ca/RegionalPlans/SouthSaskatchewan/documents/ TermsofRefDev-SouthSaskatchewanRegion-Nov26-2009.pdf> [South Saskatchewan Terms of Reference]. 
(c) to create legislation and policy that enable sustainable development by taking account of and responding to the cumulative effect of human endeavour and other events. ${ }^{36}$

This provision may be particularly valuable in future legislative analyses since, as will be discussed, many of the Act's provisions provide only a bare legislative framework.

The following is a discussion of the key components of ALSA. However, it must be noted that two important themes run through the entire enactment. First, there are broad discretionary powers vested in Cabinet by the Act. Second, there are very limited means by which to object to the Act or challenge actions or decisions taken pursuant to the Act, including the content of the regional plans and the manner in which they are applied.

\section{A. THE SCOPE AND APPLICATION OF THE ALBERTA LAND STEWARDSHIP ACT}

ALSA applies to any "activity," defined as anything requiring statutory consent and "anything that, under an enactment, must comply with a rule, code of practice, guideline, directive or instrument." "Statutory consent" is broadly defined as meaning "a permit, licence, registration, approval, authorization, disposition, certificate, allocation, agreement or instrument issued under or authorized by an enactment or regulatory instrument." 38 As a result, any activity that is currently being conducted or is proposed to be conducted pursuant to a statutory consent is subject to $A L S A$. ALSA is superordinate legislation having supremacy over all other provincial enactments. ${ }^{39}$ Further, $A L S A$ expressly amends 27 provincial Acts. ${ }^{40}$ Twenty-five of these amendments came into force on 1 October 2009. These amendments largely provide legal direction to the government agencies and decision-makers responsible for administering these enactments that their actions are now subject and subordinate to ALSA and its regional plans. For instance, s. 16 of the Mines and Minerals Act, being the section that authorizes the Minister to grant petroleum, natural gas, and oil sands licences and

\footnotetext{
Supra note 6.

Ibid., s. 2(a).

Ibid., s. 2(aa).

Ibid., s. 17(4).

Administrative Penalties and Related Matters Statutes Amendment Act, 2002, S.A. 2002, c. 4; Agricultural Operation Practices Act, R.S.A. 2000, c. A-7; Agricultural Pests Act, R.S.A. 2000, c. A-8; Alberta Utilities Commission Act, S.A. 2007, c. A-37.2; Coal Conservation Act, R.S.A. 2000, c. C-17; Electric Utilities Act, S.A. 2003, c. E-5.1; Energy Resources Conservation Act, R.S.A. 2000, c. E-10 [ERCA]; EPEA, supra note 24; Forests Act, R.S.A. 2000, c. F-22; Highways Development and Protection Act, S.A. 2004, c. H-8.5; Historical Resources Act, R.S.A. 2000, c. H-9; Interpretation Act, R.S.A. 2000, c. I-8; Irrigation Districts Act, R.S.A. 2000, c. I-11; Mines and Minerals Act, R.S.A. 2000, c. M-17 [MMA]; Municipal Government Act, R.S.A. 2000, c. M-26; Natural Resources Conservation Board Act, R.S.A. 2000, c. N-3; Oil and Gas Conservation Act, R.S.A. 2000, c. O-6; Oil Sands Conservation Act, R.S.A. 2000, c. O-7; Pipeline Act, R.S.A. 2000, c. P-15; Post-secondary Learning Act, S.A. 2003, c. P-19.5; Provincial Parks Act, R.S.A. 2000, c. P-35; Public Highways Development Act, R.S.A. 2000, c. P-38; Public Lands Act, R.S.A. 2000, c. P-40 [PLA]; Water Act, R.S.A. 2000, c. W3; Wilderness Areas, Ecological Reserves, Natural Areas and Heritage Rangelands Act, R.S.A. 2000, c. W-9; Wildlife Act, R.S.A. 2000, c. W-10.
} 
leases, is amended to ensure that the disposition process complies with any development restrictions imposed in the regional plans. Section 16 now reads as follows:

Subject to this Act and the regulations and any express provision in any applicable ALSA regional plan limiting mineral development within a geographic area, the Minister may issue an agreement in respect of a mineral

(a) on application, if the Minister considers the issuance of the agreement warranted in the circumstances,

(b) by way of sale by public tender conducted in a manner determined by the Minister, or

(c) pursuant to any other procedure determined by the Minister. ${ }^{41}$

With similar effect, a new s. 3.1 has been added to the Energy Resources Conservation Act. It reads: "In carrying out its mandate under this Act and other enactments, the Board must act in accordance with any applicable ALSA regional plan.”42

ALSA also makes extensive substantive and structural amendments to the Forests Act and the Public Lands Act. The amendments to the Forests Act include acknowledgment of the authority of regional plans over forestry plans and dispositions, ${ }^{43}$ while the PLA amendments include provisions enabling the development of regulations to manage access to vacant public lands, ${ }^{44}$ and new tools, such as stop work orders and disposition suspensions, to mitigate damage to public land. ${ }^{45}$ Both the Forests Act and the PLA were also amended to include a framework to appeal decisions. ${ }^{46}$

ALSA creates an exemption to its supremacy as it grants Cabinet the unfettered discretionary authority to exempt any entity from the definition of "local government body" or "decision-making body" and exempt any instrument from the definition of "regulatory instrument." 47 This provision has been criticized by some non-industry stakeholders who believe that it undermines the integrity of the Framework by potentially allowing the regulatory review process for a significant development to be done in isolation of the governing regional plan.

The government has defended this discretionary authority on two grounds. First, the undertaking contemplated in the Framework is a monumental task and, as it is impossible to anticipate all potential problems, wide discretionary powers are necessary. Second, the government has expressed a strong desire to keep this regime within the control of "Albertans," 48 which some say means that the government intends to keep control of the

MMA, ibid. [emphasis added].

ERCA, supra note 40.

Supra note 40, s. 45.1.

Supra note 40, ss. 8-9.

Ibid. ss. 26, 59.2.

Forests Act, supra note 40, Part 5; ibid., Part 7.

Supra note 6, s. 66.

Legislative Assembly, Alberta Hansard, Issue 47a (2 June 2009) at 1503 (Ted Morton). 
regime rather than having it subject to the discretion of the courts. ${ }^{49}$ The Framework is still in the early stages of implementation and therefore it remains to be seen how the government will exercise these broad discretionary powers and whether in doing so it will deviate from the Framework's key strategies.

\section{B. Planning Regions and Regional Plans}

Whereas the Framework contemplates the creation of seven planning regions along the boundaries of Alberta's major watersheds, ALSA leaves the creation of the planning regions and their boundaries to the discretion of Cabinet. ${ }^{50}$ Accordingly, there is no certainty provided in the Act that all parts of the province will be subject to the Framework.

ALSA also departs from definitive statements in the Framework by stating that the creation of each regional plan is within the unfettered discretion of Cabinet. ${ }^{51}$ Whereas the Framework provides a lengthy list of elements to be contained in each regional plan, ALSA only requires each plan to "describe a vision" and "state one or more objectives for the

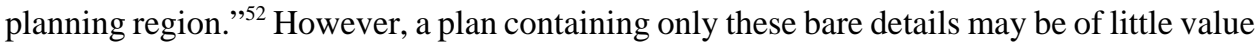
to those making decisions as to how activities should be conducted in the region. If Cabinet is serious about implementing the Framework it will include in each regional plan some or all of the discretionary content described in the Act, which includes:

- a description of the matters of particular importance to the planning region and the trends, opportunities, and challenges for the planning region;

- policies and thresholds "designed to achieve or maintain the objectives for the planning region";

- the actions or measures that are "to be taken to achieve or maintain the objectives and policies in the regional plan” and the actions or measures to be taken if a threshold is jeopardized or an objective or policy is not achieved or maintained;

- the indicators that are to be used to determine or assist in determining whether objectives and policies in the regional plan are being achieved or whether such objectives and policies are working;

- the process for monitoring thresholds, indicators, and policies, including how frequently such activities should be conducted and to whom such information should be reported to; and

- the appointment of persons responsible for the foregoing. ${ }^{53}$

See e.g. ibid. at 1505 (Hugh MacDonald).

ALSA, supra note 6 , s. 3(1).

Ibid., s. 4.

Ibid., s. 8.

Ibid., ss. 7, 8(2). 
ALSA's lack of detailed mandatory content also leaves the process ripe for inconsistency between regional plans. Since each region is unique, each region's plan will be different. However, without more stringent mandatory requirements the scope and substance of the plans may vary dramatically.

A power granted in ALSA, but not contemplated in the Framework, is that regional plans may make new regulations, or amend or appeal regulations created under another enactment. ${ }^{54}$ The definition of "regulatory instruments" encompasses regulations passed pursuant to an Act as well as rules, orders, directives, and guidelines that may be approved by a body duly authorized by Cabinet. ${ }^{55}$ This power is quite extraordinary. For instance, it could permit a regional plan to limit or change public consultation and notification requirements or change intervener standing tests for proposed developments being considered by the Energy Resources Conservation Board (ERCB) or Alberta Environment (AENV). If this were to happen in some regions but not others this could create an unduly complicated regulatory regime. ALSA further permits regional plans to create new offences, penalties, fines, and other enforcement mechanisms to deal with actions that contravene that plan, or to identify fines, penalties, and other enforcement mechanisms in other enactments that will apply to a contravention of that plan. ${ }^{56}$

These extraordinary powers have the potential to create serious regulatory disruption as a particular type of land use (for instance, a wellsite) could encounter different rules in each planning region. It could also mean that existing regulations may be amended differently by different regional plans, resulting in disparate versions of a single piece of legislation. Consequently, as the regional plans are approved they will have to be closely reviewed in order to see if any new regulations or amendments to existing regulations have been created and, if so, whether they are consistent with existing laws and regulations.

\section{SUBREgIONAL Plans}

As identified in the Framework, metropolitan plans are being developed for the Capital and Calgary regions. When completed they will become part of the applicable regional plans. ${ }^{57}$ ALSA provides for the inclusion of these metropolitan plans and any other subregional plans or issue-specific plans. ${ }^{58} A L S A$ further enables a regional plan to adopt, by incorporation, other government initiatives. It could, by consequence of incorporating a government policy, give the policy the force of law. ${ }^{59}$

Ibid., s. 9(2)(d).

The only rules, orders, directives, or guidelines that a regional plan may not amend are those under the Metis Settlements Act, R.S.A. 2000, c. M-14: see ibid., ss. 2(w), 17(2).

ALSA, ibid., s. 9(3).

The Capital metropolitan plan is being developed by the Capital Region Board: see Capital Region Board, Growing Forward: The Capital Region Growth Plan (Edmonton: Capital Region Board, 2009), online: Capital Region Board <http://capitalregionboard.ab.ca/images/Documents/Plan/crb_growthplan _e.pdf $>$. The Calgary metropolitan plan is being developed by the Calgary Regional Partnership: see Calgary Regional Partnership, Calgary Metropolitan Plan (Cochrane, Alta.: Calgary Regional Partnership, 2009), online: Calgary Regional Partnership <http://calgaryregion.ca/crp/media/57225/crp \%20cmp\%20final.pdf>

Supra note 6, s. 10 .

The failure to make prior land management policies developed in the province binding legal commitments is frequently cited as a reason such policies were not as successful as initially expected: see Kennett, supra note 17 at 14-15. 


\section{No CAUSE OF ACTION OR JUDICIAL REVIEW}

ALSA expressly provides that the binding nature of a regional plan "does not create or provide any person with a cause of action or a right or ability to bring” any court application or appeal right before a decision-maker, nor does it "confer jurisdiction on any court or decision-maker to grant relief in respect of a claim." 60 There is a limited exception for the Commissioner (defined below) to apply to the Court of Queen's Bench for an order to remedy or rectify any decision that is not in compliance with a regional plan. ${ }^{61}$

\section{The Nature ANd Effect of Regional Plans}

ALSA provides that "[r]egional plans are legislative instruments and, for the purposes of any other enactment, are considered to be regulations." ${ }^{62}$ In the event of conflict with a "regulatory instrument," the regional plan prevails. ${ }^{63}$ The Act further provides that

[e]xcept to the extent that a regional plan provides otherwise, a regional plan binds
(a) the Crown,
(b) local government bodies,
(c) decision-makers, and
(d) all other persons. ${ }^{64}$

The superordinate authority of regional plans is limited only in the event of a conflict or inconsistency with an Act (other than ALSA), a General Council Policy, or a Co-Management Agreement under the Metis Settlements Act. ${ }^{65}$ This restriction, however, is likely of nominal relevance as ALSA provides that if there is a conflict or inconsistency with another enactment, $A L S A$ supercedes. ${ }^{66}$ Since regional plans will be enacted pursuant to $A L S A$ and a conflict between a regional plan and another enactment may also result in a conflict between that enactment and ALSA, a situation could arise where an offending enactment is superseded by a regional plan.

ALSA defines a “decision-maker” as “a person who, under an enactment or regulatory instrument, has authority to grant a statutory consent, and includes a decision-making body." ${ }^{, 7}$ Accordingly, all matters that relate to land use are subject to the regional plans (except for decisions made under the Metis Settlements Act). This means that all existing or

$60 \quad$ Supra note 6, s. 15(3).

Ibid., ss. 15(5), 18. In the recent decision of Keller v. Municipal District of Bighorn No. 8, 2010 ABQB 362, [2010] A.J. No. 606 at para. 52 (QL) [Keller], the Court upheld s. 18, finding that persons other than the Commissioner were excluded "from bringing an application for judicial review on the basis of non-compliance with ALSA.”

ALSA, ibid., s. 13(2).

Ibid., s. 17(1)(b).

Ibid., s. 15(1).

Ibid., ss. 17(2)-(3).

Ibid., s. 17(4).

Ibid., s. 2(e). 
future oil, gas, and oil sands activities that require regulatory approval from the ERCB, AENV, Alberta Sustainable Resource Development (SRD), or any other decision-maker will be subject to the applicable regional plan.

ALSA further provides that once a regional plan becomes effective, every local government body and decision-maker must review its regulatory instruments and make any necessary changes, or implement new initiatives to comply with the regional plan. ${ }^{68}$ They must also file a statutory declaration with the Secretariat stating that the review is completed and that they are in compliance with the regional plan. ${ }^{69}$ This process is also required each time a regional plan is amended, a subregional plan or issue-specific plan is adopted or amended, and when an agreement or arrangement is adopted in a regional plan. ${ }^{70}$ Since the government has elected to undertake a staged approach to developing the regional plans, decision-makers may have to undertake seven separate reviews, and potentially seven different revisions, to their regulatory instruments given that seven regional plans are to be created.

\section{THE LAND-USE SECRETARIAT AND THE REGIONAL ADVISORY COUNCILS}

ALSA provides for the creation of a Secretariat (independent of any other government department) and the appointment of a Secretariat Commissioner (Commissioner) as head of the Secretariat. ${ }^{71}$ As contemplated in the Framework, the Secretariat's role is to facilitate the development and implementation of the regional plans. ${ }^{72}$ The Secretariat is also responsible for coordinating the data collection, monitoring, and reporting systems contemplated in the Framework. ${ }^{73}$ The Secretariat may make recommendations to local government bodies and government departments regarding implementation of the regional plans and take action if there is a lack of progress in achieving or maintaining an objective or policy in a regional plan. ${ }^{74}$ As discussed below, the Secretariat may also address non-compliance with regional plans.

As contemplated in the Framework, ALSA provides for the creation of RACs at the discretion of Cabinet. ${ }^{75}$ Unlike the Framework, which contemplates each RAC being comprised of individuals representing various backgrounds and experiences relevant to the planning region, ALSA only requires the inclusion of Aboriginal peoples in a $\mathrm{RAC}^{76} \mathrm{ALSA}$ requires the mandate of each RAC to be established by terms of reference provided by Cabinet. ${ }^{77}$ However, little guidance is provided as to the content of the terms of reference; rather, ALSA focuses on the mechanical components necessary for the effective functioning of the RACs.

Ibid., ss. 20-21.

Ibid., ss. 20(2)(b), 21(2)(b).

Ibid., s. 22.

Ibid., s. 57.

Ibid., s. 59.

Ibid., s. 60.

Ibid., s. 58.

Ibid., s. 52.

Ibid., s. 52(2)(a).

Ibid., s. 53. 
It is important to note that, despite the Framework's emphasis on the need for stakeholder and public consultations in the development and implementation of the regional plans, $A L S A$ does not require a RAC to undertake any public consultation, nor does it require Cabinet to consider the advice of the Secretariat or the RACs, or approve regional plans that are consistent with the advice provided by the Secretariat or a RAC. ${ }^{78}$ However, despite this lack of direction on consultation, the two RACs created to date have used a multi-stakeholder approach and each has commenced a public consultation process.

\section{E. Reviewing ANd Amending a Regional Plan}

A management program as complex and comprehensive as that envisioned for the regional plans requires flexible amendment procedures to adapt to changing circumstances. Unfortunately, ALSA does not establish triggers (time or event based) that initiate a review or establish guidelines for consultation during any review or prior to approving amendments, and there is no means by which a person may request or compel a review or amendment of a regional plan. However, ALSA does give the Secretariat the authority to appoint a committee at least once every five years to evaluate the objectives and policies of the regional plans, and it does state that a review of a plan shall be conducted at least every ten years. $^{79}$

\section{F. The Compliance Review And Appeal Process}

Central to the accountability and enforcement of the Framework is compliance with regional plans. When the Bill preceding ALSA was initially introduced, some non-industrial groups argued for the creation of specialized appeal tribunals to resolve disputes regarding the inconsistency of land use decisions with regional plans, with a means to appeal decisions of these tribunals to the courts on points of law and jurisdiction. ${ }^{80}$ However, such tribunals and appeal mechanisms were not incorporated into ALSA. Rather, ALSA provides that if a person believes a decision has been made that is not in compliance with a regional plan they may use any existing review or appeal process of the decision-maker that made the aggrieved decision, or alternatively submit a complaint to the Secretariat. The Act reads that

[t]he secretariat may investigate a complaint of non-compliance if the commissioner is satisfied that

(a) the complaint has or may have sufficient merit to warrant an investigation,

(b) the matter complained of is not the subject or part of the subject of an application, process, decision or appeal governed by an enactment or regulatory instrument, or that there is not an adequate remedy under the law or existing administrative practices, and

(c) no other person should investigate the matter complained of. ${ }^{81}$

Ibid., s. 5(1).

Ibid., ss. 58-59.

Kennett, supra note 17 at 4.

ALSA, supra note 6, s. 62(2). 
This use of existing review and appeal processes minimizes the creation of new bureaucratic structures and preserves established mechanisms, jurisprudence, and expertise. For instance, a complaint about an ERCB decision will be addressed through the Board's review and variance process and, ultimately, its judicial review process. ${ }^{82}$ Similarly, allegations of non-compliance regarding a decision made by AENV will be handled by appeals to the Alberta Environmental Appeals Board and, if eligible, by judicial review to the Alberta Court of Queen's Bench. ${ }^{83}$ To further reduce the need for the Secretariat to review allegations of non-compliance, the Forests Act and the PLA have, as stated above, been amended to provide for the creation of a review and appeal process. ${ }^{84}$

If the Commissioner determines that a complainant satisfies s. 62(2) and a resulting investigation finds that the decision is not compliant with the regional plan, the Commissioner may refer ("with or without a report or recommendations") the matter back to the decision-maker. ${ }^{85}$ ALSA does not grant the Commissioner the right to impose sanctions or other penalties against the offending decision-making authority. Furthermore, it is only in instances where the Commissioner feels that no remedy is available under any other enactment that the Commissioner may apply to the courts for an order to remedy the noncompliance. $^{86}$

\section{G. CONSERVATION AND STEWARDSHIP TOOLS}

Part 3 of ALSA uses a mix of old and new conservation and stewardship tools: conservation easements, conservation directives, stewardship units, conservation offsets, and transferable development credits. These tools have the potential to dramatically affect oil and gas activities.

A conservation easement is a voluntary legal agreement whereby the registered owner of land grants rights to restrict the use and development of their land to a "qualified organization,” which includes the province, a municipality, corporation, or a registered charity that has as one of its objects the acquisition and holding of land for conservation purposes. ${ }^{87}$ Prior to ALSA, conservation easements were found under the EPEA; prior to the EPEA, Alberta landowners wishing to protect their land had to rely upon common law restrictive covenants.

A conservation directive is a declaration in a regional plan to "permanently protect, conserve, manage and enhance environmental, natural scenic, esthetic or agricultural values" of specified land parcels. ${ }^{88}$ Conservation directives have the potential to significantly impact oil and gas activities by not only restricting or prohibiting future activities on lands that are

Pursuant to ss. 40 and 41 of the ERCA, supra note 40, the ERCB has a review and variation process and there exists a right to seek leave to appeal to the Alberta Court of Appeal.

Approvals of AENV may, pursuant to Part 4 of the EPEA, supra note 24 and Part 9 of the Water Act, supra note 40, be reviewed by the Environmental Appeals Board and leave may be sought to the Alberta Court of Queen's Bench to conduct a judicial review of decisions of the Environmental Appeals Board. Forests Act, supra note 40, Part 5; PLA, supra note 40, Part 7.

ALSA, supra note 6, s. 62(6).

Ibid., s. 18.

Ibid., s. 28(c).

Ibid., s. 37(1). 
the subject of a directive, but also causing existing activities to cease or operate in a different and perhaps more costly manner.

A title holder whose estate or interest is the subject of a conservation directive has one of the few statutory rights under ALSA to apply to the Land Compensation Board (LCB) (or to the Métis Settlements Appeal Tribunal Land Access Panel in the case of Métis settlement lands) for compensation to be paid by the Crown. ${ }^{89}$ According to s. 39(3) of the Act, the title holder is entitled to compensation for

(a) the amount of decrease in the market value of the estate or interest in land

(i) resulting solely from the express declaration of the conservation directive, and

(ii) determined as of the date the conservation directive became effective. ${ }^{90}$

The “'market value' ... is the amount that the estate or interest might be expected to realize if sold on the open market by a willing seller to a willing buyer." ${ }^{11}$ The title holder is also entitled to damages for injurious affection and "for any other loss specified in the regulations." 92 As is the case elsewhere in ALSA, extensive powers are given to Cabinet to make regulations with respect to conservation directives, including the process for a title holder to obtain compensation. ${ }^{93}$

A "title holder" includes the registered owner, a person who is shown at the "land titles office as having an estate or interest in the land," any person "in possession or occupation of the land" and, "in the case of Crown land, a person shown on the records of the department administering the land as having an estate or interest in the land." 94 An oil and gas operator who holds a surface access right is a title holder and prima facie entitled to compensation. However, ALSA expressly excludes within the definition of title holder a person who holds a disposition under the $M M A$, has an interest in a unit agreement, or a contract under s. 9(a) of the $M M A$, such as a gas storage facility operator. ${ }^{95}$ Hence, an oil and gas operator would appear to be entitled to the market value of their surface interest but not for their mineral rights, which may be undevelopable if a conservation directive prohibits industrial activities on the surface. It is not known how compensation will be determined in such a situation because surface rights are rarely transferred by themselves without mineral rights, and therefore difficulties may arise in determining fair market value. It is also not known how a conservation directive that requires the termination of existing industrial surface activity will accommodate any existing legal obligations of an operator to conserve

Ibid., ss. 39-41.

Ibid.

Ibid., s. 39(4).

Ibid., ss. 39(3)(b)-(c). Injurious affection is the principle that compensation is recoverable not only for the value of land taken but also for consequential damage to other property. The Supreme Court of Canada in British Columbia (Minister of Transportation and Highways) v. British Pacific Properties Ltd., [1960] S.C.R. 561 at 567, described it as: "where a statute requires compensation to be paid for lands compulsorily taken, one element to be included, in determining the compensation for the lands taken, is in respect of damage sustained by the owner, by reason of injurious affection to his adjoining lands, because of the severance."

ALSA, ibid., s. 43.

Ibid., s. 2(gg).

Ibid., ss. 2(gg)(iii)-(v). 
and reclaim specified land under the EPEA, especially given the paramountcy of regional plans over other legislation.

Another key provision of $A L S A$ that could significantly impact existing and future oil and gas activities is s. 47, which enables Cabinet to pass regulations requiring persons to "counterbalance the effect of an activity." 96 As mentioned in Part III.A, above, an activity is anything that requires a statutory consent or anything under an enactment that must comply with a rule, code of practice, guideline, directive, or instrument. As many oil and gas operations are regulated by statutory consents, codes of practice, or directives, future Cabinet regulations may require the operator to counterbalance the effects of existing or proposed operations. Cabinet may also require a decision-maker, such as the ERCB, "to impose terms and conditions on an existing or proposed statutory consent to counterbalance the effect of an activity or proposed activity., 97

The definition of counterbalancing includes "avoiding, limiting or mitigating the adverse effects of an activity," or minimizing its impact by "limiting the magnitude or degree of the activity." ${ }^{98}$ Counterbalancing can also be accomplished by "rectifying or reducing an adverse effect” of an activity "by repairing, rehabilitating, restoring or reclaiming” land, or by compensating for the effects of an existing or proposed activity by undertaking conservation activities elsewhere. ${ }^{99}$ The specific requirements of regulations prescribing counterbalancing are not yet known but they could have significant impact on both existing and future oil and gas activities, including imposing costly obligations that could render certain oil and gas activities uneconomic.

Linked to ALSA's provisions enabling the creation of counterbalancing regulations are new, potentially complex, market-based instruments such as conservation offsets, stewardship units, and transferable development credits. Some may argue that traditional command-and-control regulatory techniques, such as the use of prescriptive regulations and the issuance of environmental protection orders and directives, are sufficient to conserve and protect Alberta's natural capital. However, others argue that there can be no substantive, long-term solution to the problem of environmental degradation without the utilization of market principles and mechanisms.

The idea behind a conservation offset is that negative impacts to an area, associated with an activity, are mitigated through conservation or restoration efforts at some other area so that, on a regional basis, there is no net loss caused by the activity. The use of offsets is not new to Canadian environmental law. For example, Fisheries and Oceans Canada (DFO) has developed a habitat compensation program ${ }^{100}$ for projects that are likely to result in the harmful alteration, disruption, or destruction of fish habitat under the Fisheries Act. ${ }^{101}$ This "no net loss” policy defines "compensation for loss" as the "replacement of natural habitat"

100 Fisheries and Oceans Canada, Policy for the Management of Fish Habitat (Ottawa: Supply and Services Canada, 1986), online: Fisheries and Oceans Canada <http://www.dfo-mpo.gc.ca/habitat/role/ 141/1415/14155/fhm-policy/pdf/policy-eng.pdf> [Fish Habitat Management Policy]. 
or the "increase in the productivity of existing habitat" where mitigation techniques and other measures applied to a project are not adequate to maintain fisheries resources. ${ }^{102}$ Although DFO's first preference is for a project to avoid any harmful alteration, disruption, or destruction of fish habitat, it is recognized that sometimes not all of a project's adverse effects may be avoided through project relocation, redesign, or mitigation. Compensation is only considered after it is proven to be "impossible or impractical" to avoid impacting fish habitat. ${ }^{103}$ DFO's compensation program uses a hierarchy of compensation options, with the preferred option being the creation or increase in like-for-like habitat in the same ecological unit, followed by creating or increasing unlike habitat in the same unit or a different unit. ${ }^{104}$ A greater than 1:1 compensation ratio is required to recognize both that it takes time for new habitat to become functional and that, in some circumstances, the compensation may not function as anticipated.

Another example is with respect to wetland compensation. At a provincial level, Alberta's Water Act requires an approval to be obtained for a project to impact a wetland. ${ }^{105}$ Although AENV's policy is to avoid impacts to wetlands whenever possible, when not possible, developers must compensate for their project's impacts by restoring previously drained or altered naturally occurring wetlands. ${ }^{106}$ As it is almost impossible to fully replicate the complexity of a natural wetland ecosystem, generally a minimum ratio of 3:1 is common, with three hectares of equivalent wetland restored in the same local watershed for each hectare of natural wetland impacted or lost by a project. If the restoration is outside of the local watershed, the ratio increases with the distance from the project site, to a maximum 10:1 ratio for restoration sites 80 or more kilometres from the wetland disturbed by the project. Determination of replacement ratios is not an exact science and is usually negotiated with AENV. At the federal level, The Federal Policy on Wetland Conservation administered by Environment Canada also includes a "no net loss” goal and a compensation strategy. ${ }^{107}$

Under ALSA, conservation offsets and stewardship units are to be regulated by future Cabinet regulation. ${ }^{108}$ Implementation of a market-based system for these instruments will require the creation of a sophisticated legal regime that currently does not exist in the province. This regime will likely be similar to the market-based emission offset program and offset protocols that are being developed under the Specified Gas Emitters Regulation. ${ }^{109}$

A transferable development credit (TDC) scheme ${ }^{110}$ involves the concept of conserving an identified land value, such as important wildlife habitat, by transferring the subdivision or development potential from that land to other land. TDC schemes allow authorities to direct development away from areas threatened by it, toward more suitable areas by allowing

Fish Habitat Management Policy, supra note 100 at 26.

Ibid. at 21.

Ibid.

See Water Act, supra note 40, Part 1.

The compensation process does not allow for the development of new artificial wetlands.

Environment Canada, The Federal Policy on Wetland Conservation (Ottawa: Supply and Services Canada, 1991) at 7, online: Environment Canada <http://dsp-psd.pwgsc.gc.ca/Collection/CW66-1161991E.pdf>.

See ALSA, supra note 6, ss. 45-47.

Alta. Reg. 139/2007.

TDC schemes are also called "transfer of development rights" schemes, or "transfer of subdivision density" schemes. 
development rights to be bought and sold in an open market. Landowners in designated "sending” areas with valued landscapes can sell their development potential to landowners in designated "receiving" areas, who in turn may increase development intensity beyond a base amount allowed by their land use zoning. The sending areas then have their development potential extinguished and their title encumbered with a restriction against future development. TDC schemes have been used for several years in Alberta ${ }^{111}$ and for many years in the U.S. ${ }^{112}$ TDC schemes may offer advantages to planning authorities who are mandated with promoting increased land use in some areas, but who also face demands for compensation from landowners in areas where they restrict development. TDC schemes may be able to compensate landowners to some extent for lost property values when their property is effectively down zoned for preservation purposes, while at the same time focusing development on areas pre-selected for higher density activity. Using a TDC scheme may also reduce the need for governments to find funding to protect open spaces or achieve other landscape or preservation goals.

ALSA authorizes the establishment of a TDC scheme by a regional plan or one or more local authorities under land use plans and land use bylaws. ${ }^{113}$ ALSA enables Cabinet to make regulations respecting the components of a TDC scheme. The Act itself requires that every TDC scheme must not only designate areas of land as conservation areas and development areas, but also set the attributes of the stewardship units established by the TDC scheme and "the terms and conditions under which a stewardship unit may be realized or used."114

A stewardship unit is not well defined in $A L S A^{115}$ and details about what they may be, how they may be used, and their attributes are left to Cabinet for future regulation. ${ }^{116}$ The idea behind using habitat, or some other attribute of a landscape, as a "currency" that can be traded may be repugnant to some people, but it may also approximate a value for habitat beyond common valuations of land that typically focus on the highest and best human use.

To help facilitate the recording and transfer of stewardship units within a TDC scheme, ALSA contemplates an exchange that will "create, hold, issue, approve, verify, authenticate, distribute,” manage, and extinguish stewardship units. ${ }^{117}$ Like many other parts of $A L S A$, the details of the stewardship unit exchange are left for future regulations.

For example, in 1996 the Municipal District of Bighorn created a small holdings area in its municipal plan that allowed for the subdivision of 160 acre sections into four parcels of approximately equal size in the Jamieson Road area. In 2006, with municipal approval, a landowner transferred the subdivision and development rights from eight quarter sections to four other quarter sections, allowing for up to 45 lots on the four quarter sections instead of the 16 lots otherwise allowed under the small holdings area designation. Conservation easements were placed on the eight sending quarter sections prohibiting future subdivision and development: see Keller, supra note 61.

The idea of transferring development rights between properties was first introduced in New York City in 1916 with the passage of the first comprehensive zoning ordinance in the U.S. It allowed landowners to sell their unused air rights to adjacent lots, which could then exceed existing height and setback requirements: see “About NYC Zoning," online: New York City Department of City Planning <http://www.nyc.gov/html/dcp/html/zone/zonehis.shtml>. ALSA, supra note 6, s. 48.

Ibid., s. 49.

See ibid., s. 2(dd).

Ibid., s. 46.

Ibid., s. 45(b)(i). 
There are several issues facing the development of this mechanism. The identification of areas where conservation is sought, and other areas where development is encouraged, may be difficult. One assumes that a working market requires that development areas face a demand for more development than allowed under their present land use bylaws. It also may be possible for local citizens, land trusts, and other groups to buy development rights and simply retire them without transferring them to a development area. Further, every parcel within both the conservation area or the development area has to be allocated a conservation or development value. It is unclear if this will be based on the development potential, some conservation criteria, or on a one-parcel-one-unit basis. Deciding which parcels are entitled to a unit will be a matter of some consequence and undoubtedly, at times, great controversy. Further, a critical aspect of any TDC scheme will be the mechanism used to perpetually extinguish the development potential of a conservation parcel. It appears that ALSA is contemplating the use of conservation easements in this regard, as is common with other transfer of development schemes. Finally, a TDC scheme may be more complicated and expensive to implement than traditional zoning, as resources are required to educate the public, developers, and industry, oversee the market, track and monitor title restrictions, and administer the exchange.

\section{IMPLEMENTATION OF THE ALBERTA LAND STEWARDSHIP ACT}

As explained above, ALSA has been criticized on a number of fronts, and perhaps most consistently on the extensive discretionary powers it grants to Cabinet. However, based on the actions of the government to date, the fears associated with such broad discretionary authority appear, so far, to be overstated. To date, the government has largely acted in a manner consistent with the goals and strategies of the Framework. It has commenced the planning process for the development of a regional plan for each of the Lower Athabasca and South Saskatchewan planning regions. For each of these regions it has released terms of reference, which include all of the elements initially identified in the Framework, created RACs, and appointed RAC members who will be able to provide a variety of regional economic, environmental, and social expertise and experiences.

\section{A. The Lower Athabasca Regional Plan}

Promptly after enacting ALSA, the government established the RAC for the Lower Athabasca planning region (LA-RAC). The LA-RAC is composed of 17 members representing a cross-section of interests, including municipal and provincial bodies, industry, Aboriginal groups, and environmental groups and is chaired by the Assistant Deputy Minister in the government's Oil Sands Secretariat. In May and June of 2009 it hosted 13 public information sessions within the region to provide information about the Framework and the purpose of the LA-RAC. ${ }^{118}$ 
On 31 July 2009, the government released the profile of the region and the terms of reference for the Lower Athabasca Regional Plan (LARP). ${ }^{119}$ The profile provides a background of the region and describes the key issues currently impacting and likely to continue impacting the region. The terms of reference request the LA-RAC to provide advice and recommendations on a number of key matters, as follows:

- details of the economic, environmental, and social implications associated with three economic development scenarios, ${ }^{120}$ including specific thresholds for water withdrawals and air quality;

- means to achieve two land conservation scenarios, including identifying the land within the region that could be used to achieve these scenarios; ${ }^{121}$

- identification of the general location for major utility and transportation corridors in the region (this work is intended to support the provincial transportation and utility corridors policy that is currently being developed); ${ }^{122}$

- means to increase tourism in the region, with emphasis on Lakeland County; ${ }^{123}$

- options for recreational development on Crown land in the region; ${ }^{124}$ and

- the impact of development on Aboriginal communities in the region. ${ }^{125}$

The two land conservation scenarios set aside 16 percent of the land in the region for conservation purposes, with the possibility of conserving more than 20 percent of the land in the region. ${ }^{126}$ Preference is to be given to areas with little or no industrial activity, but the government acknowledges that such conservation efforts are likely to adversely affect existing mineral grants, particular in the more ambitious 20 percent conservation scenario. ${ }^{127}$ What will concern companies having an interest in mineral leases in this region is the government's expressed intention to cancel mineral leases, if necessary, to achieve its goals and objectives for the region. ${ }^{128}$ The government has indicated that preference for conservation lands will be given to northern portions of the region and therefore those leases located outside of the core Fort McMurray area are at particular risk of being cancelled.

Government of Alberta, Profile of the Lower Athabasca Region (Edmonton: Alberta Sustainable Resource Development, 2009), online: Alberta Sustainable Resource Development <http://www. landuse.alberta.ca/RegionalPlans/LowerAthabasca/documents/ProfileOfTheLowerAthabasca RegionJul2009.pdf $>$; Athabasca Terms of Reference, supra note 14.

Athabasca Terms of Reference, ibid. at 12. The economic development scenarios relate to oil sands development in the region and are: (1) a current-state scenario of 1.5 to 2.0 million barrels per day (MMbpd); (2) a mid-range scenario of 4.0 to $4.5 \mathrm{MMbpd}$; and (3) a high-end scenario of 6.0 or more MMbpd.

Ibid.

Ibid.

Ibid. at $17-18$.

Ibid. at 14 . These scenarios are to include the 6 percent of the region that is already set aside for conservation.

127 Ibid. The government contemplates that such lands will be of sufficient size $\left(4,000-5,000 \mathrm{~km}^{2}\right)$, representative of the biological diversity of the region, and capable of supporting traditional Aboriginal uses. 
In developing its advice and recommendations the LA-RAC is requested to consider 14 provincial policies, including the Water Management Framework: Instream Flow Needs and Water Management System for the Lower Athabasca River and Responsible Actions: A Plan for Alberta's Oil Sands. ${ }^{129}$

The government initially anticipated that the LARP would be approved by the end of 2010. This timeline, however, has slipped as the LA-RAC has yet to provide Cabinet with its initial advice and recommendations. The government has not stated whether this delay will affect the commencement of the development of the other regional plans.

It is worth noting that the LARP terms of reference also identified areas that the LA-RAC is not to provide advice and recommendations on, including: re-organization or restructuring of municipalities, modification of the Aboriginal consultation process, maximum caps on human population or settlement, tax policy or rates, provincial royalties, government expenditures and spending commitments, and changes to existing laws and regulations. ${ }^{130}$ These exemptions are presumably based on the government's desire to focus the RACs and prevent them from wandering into areas being addressed under other government initiatives. For instance, provincial royalties have been addressed through the recently undertaken competitiveness review and, in response to this review, the government has initiated a separate process to review existing laws and regulations. ${ }^{131}$ These other initiatives will have to be taken into account and, as a result, the regional plans may be much broader in scope than the advice and recommendations provided by the RACs might indicate.

Alberta Environment \& Fisheries and Oceans Canada, Water Management Framework: Instream Flow Needs and Water Management System for the Lower Athabasca River (Calgary: Alberta Environment, 2007), online: Alberta Environment <http://environment.alberta.ca/documents/Athabasca_RWMF_ Technical.pdf>; Government of Alberta, Responsible Actions: A Plan for Alberta's Oil Sands (Edmonton: Alberta Treasury Board, 2009), online: Alberta Treasury Board <http://treasuryboard. alberta.ca/docs/GOA_ResponsibleActions_web.pdf $>$. The other provincial policies that the LA-RAC is to consider are: Government of Alberta, Strengthening Relationships: The Government of Alberta's Aboriginal Policy Framework (Edmonton: Alberta Aboriginal Relations, 2000), online: Alberta Aboriginal Relations <http://www.aboriginal.alberta.ca/documents/final_strengthrelations.pdf > [Aboriginal Policy Framework]; Government of Alberta, Plan for Parks: 2009-2019 (Edmonton: Alberta Tourism, Parks and Recreation, 2009), online: Alberta Tourism, Parks and Recreation <http:// tpr.alberta.ca/parks/p4p/docs/P4P.pdf> [Alberta Plan for Parks]; Government of Alberta, A Place to Grow: Alberta's Rural Development Strategy (Edmonton: Alberta Agriculture and Rural Development, 2005), online: Alberta Agriculture and Rural Development < http://www1.agric.gov.ab.ca/\$department/ deptdocs.nsf/all/csi12104/\$FILE/grow-feb2005.pdf> [A Place to Grow]; Government of Alberta, Building and Enhancing Tomorrow's Workforce: Alberta's 10 Year Strategy (Edmonton: Alberta Human Resources and Employment, 2006), online: Alberta Human Resources and Employment $<$ http://employment.alberta.ca/documents/WIA/WIA-BETW_strategy.pdf> [Alberta Workforce Strategy]; Clean Air Strategy, supra note 11; Climate Change Strategy, supra note 11; Government of Alberta, Cold Lake - Beaver River Basin: Water Management Plan (Calgary: Alberta Environment, 2006), online: Alberta Environment <http://environment.alberta.ca/documents/Basin_Water_Mgmt_ Plan_2006.pdf>; Government of Alberta, Launching Alberta's Energy Future: Provincial Energy Strategy (Calgary: Alberta Energy, 2008), online: Alberta Energy <http://www.energy.gov.ab.ca/Org/ pdfs/AB_ProvincialEnergyStrategy.pdf> [Alberta Provincial Energy Strategy]; Government of Alberta, The Spirit of Alberta: Alberta's Cultural Policy (Edmonton: Alberta Culture and Community Spirit, 2008), online: Alberta Culture and Community Spirit <http://culture.alberta.ca/culturalpolicy/pdf/ SpiritofAlberta.pdf> [The Spirit of Alberta]; Government of Alberta, Vision 2020: The Future of Health Care in Alberta (Phase One) (Edmonton: Alberta Health and Wellness, 2008), online: Alberta Health and Wellness <http://www.health.alberta.ca/documents/Vision-2020-Phase-1-2008.pdf > [Vision 2020]; Water for Life, supra note 11. Athabasca Terms of Reference, supra note 14 at 8. and Conventional Oil Competitiveness (Calgary: Alberta Energy, 2010), online: Alberta Energy <http:// www.energy.alberta.ca/Org/pdfs/EnergizingInvestment.pdf>. 


\section{B. The South Saskatchewan Regional Plan}

In May 2009 the government established the RAC for the South Saskatchewan planning region (SS-RAC). It is composed of 18 members, with an additional seat reserved for a member of a Treaty 7 First Nation. It is currently chaired by an Assistant Deputy Minister of AENV.

The government released the regional profile and terms of reference in November 2009. ${ }^{132}$ The terms of reference identify population growth and water as significant issues and request the SS-RAC to explore development scenarios that consider the relationships between population growth, water supply, economic growth, and land conservation. ${ }^{133}$ Specifically, the SS-RAC is to provide recommendations on:

- development objectives that enable agriculture, energy, forestry, recreation, and tourism to succeed side by side in the region;

- ways "to the reduce the human footprint and reduce fragmentation of valued landscapes in the region";

- identify the locations of high-value recreation and tourism lands and approaches for maintaining the integrity of such lands; and

- identify lands that could meet the criteria for conservation (particularly along the Eastern Slopes) and details of the resulting development implications of such conservation measures. ${ }^{134}$

The terms of reference also request advice on general locations for major transportation and utilities corridors and the impacts on regional Aboriginal communities as a result of future development. ${ }^{135}$ As previously explained, the Framework anticipates, and the terms of reference confirm, that the Calgary Regional Partnership Metropolitan Plan, when completed, will be integrated into the South Saskatchewan regional plan. ${ }^{136}$

The SS-RAC is asked to integrate into its advice and recommendations several existing strategies and initiatives, including the Water for Life strategy. ${ }^{137}$ Since the Red Deer land

Government of Alberta, Profile of the South Saskatchewan Region (Edmonton: Alberta Sustainable Resource Development, 2009), online: Alberta Sustainable Resource Development <http://www.land use.alberta.ca/RegionalPlans/SouthSaskatchewan/documents/SSRP-ProfileOfSouthSaskatchewan Region-Nov26-2009.pdf>; South Saskatchewan Terms of Reference, supra note 35. South Saskatchewan Terms of Reference, ibid. at 11.

Ibid. at 22.

Ibid. at 27.

Ibid. at 9.

The other provincial strategies and initiatives that the SS-RAC is requested to consider in developing its advice and recommendations are: Aboriginal Policy Framework, supra note 129; Government of Alberta, Alberta Forest Management Planning Standard (Edmonton: Alberta Sustainable Resource Development, 2006), online: Alberta Sustainable Resource Development <http://srd.alberta.ca/ managingprograms/ForestManagement/documents/Alberta_Forest_Management_Planning_Standard_ Version_4_1_April_2006_Final_2.pdf> ; Clean Air Strategy, supra note 11; Alberta Plan for Parks, supra note 129; Government of Alberta, Alberta's Strategy for the Management of Species at Risk (2009-2014) (Edmonton: Alberta Sustainable Resource Development, 2008), online: Alberta Sustainable Resource Development <http://www.srd.alberta.ca/BioDiversityStewardship/SpeciesAtRisk/Albertas SpeciesAtRiskStrategy/documents/Alberta\%27sStrategyForManagementOfSpeciesAtRisk2009-14.pdf>; 
use region is part of the South Saskatchewan River basin (and its regional plan will not commence development until after approval of the South Saskatchewan regional plan), the SS-RAC is also asked to consider the water needs of the Red Deer land use region in developing its advice. ${ }^{138}$ The terms of reference for the South Saskatchewan regional plan also provide that the SS-RAC is not to consider municipal governance, Aboriginal consultation, taxation, provincial royalties, government expenditures, or existing laws and regulations. ${ }^{139}$ Further, the SS-RAC is excluded from considering changes to the province's water allocation system, as the government has initiated a separate process in this regard. ${ }^{140}$

To date the SS-RAC has completed an initial round of public consultation and is developing its advice and recommendations for the regional plan. ${ }^{141}$ The government has stated that it expects the timing for development and approval of the original plan will be similar to that for the LARP.

\section{Transitional Provisions}

Other than addressing the handling of conservation easements (as their regulation moves from the EPEA to ALSA), ALSA does not state what happens between the time the Act is enacted and the time when the regional plans are approved. This lack of transitional provisions may cause cautious operators to delay project proposals until more certainty can be found in at least the draft regional plans. This may be of particular concern for projects

A Place to Grow, supra note 129; Bow, Oldman and South Saskatchewan River Basin Water Allocation Order, Alta. Reg. 171/2007; Alberta Workforce Strategy, supra note 129; Climate Change Strategy, supra note 11; Government of Alberta, Fish Conservation Strategy for Alberta (Edmonton: Alberta Sustainable Resource Development, 2006), online: Alberta Sustainable Resource Development <http:// www.srd.alberta.ca/ManagingPrograms/FishWildlifeManagement/FisheriesManagement/documents/ FishConservStrat.pdf>; Alberta Provincial Energy Strategy, supra note 129; Oldman River Basin Water Allocation Order, Alta. Reg. 319/2003; The Spirit of Alberta, supra note 129; Vision 2020, supra note 129; Alberta Environment, Water Conservation Objective, "Establishment of Bow River Sub-Basin Water Conservation Objectives" (16 January 2007), online: Alberta Environment <http://environment. alberta.ca/documents/WCO_Bow_River.pdf>; Alberta Environment, Water Conservation Objective, "Establishment of Oldman River Sub-Basin Water Conservation Objectives” (16 January 2007), online: Alberta Environment <http://environment.alberta.ca/documents/WCO_Oldman_River.pdf>; Alberta Environment, Water Conservation Objective, "Establishment of Red Deer River Sub-Basin Water Conservation Objectives” (16 January 2007), online: Alberta Environment <http://environment.alberta. ca/documents/WCO_Red_Deer_River.pdf>; Alberta Environment, Water Conservation Objective, "Establishment of South Saskatchewan River Sub-Basin Water Conservation Objectives” (16 January 2007), online: Alberta Environment <http://environment.alberta.ca/documents/WCO_South_ Saskatchewan_River.pdf $>$; Water for Life, supra note 11; Government of Alberta, Approved Water Management Plan for the South Saskatchewan River Basin (Alberta) (Calgary: Alberta Environment, 2006), online: Alberta Environment <http://environment.alberta.ca/documents/SSRB_Plan_ Phase2.pdf>; Government of Alberta, Water Management Plan for the Watersheds of the Upper Highwood and Upper Little Bow Rivers, vol. 1 (Calgary: Alberta Environment, 2008), online: Alberta Environment <http://environment.gov. ab.ca/info/library/7977.pdf >; Government of Alberta, Water Management Plan for the Watersheds of the Upper Highwood and Upper Little Bow Rivers, vol. 2 (Calgary: Alberta Environment, 2008), online: Alberta Environment <http://environment.gov.ab.ca/ info/library/7978.pdf>.

South Saskatchewan Terms of Reference, supra note 35 at 14.

Ibid. at 8 .

Ibid. Details of Alberta's Water Allocation Management System Review are available online: Government of Alberta <http://www.waterforlife.alberta.ca/563.html>.

A summary of the feedback the SS-RAC received during the initial round of public consultation is available online: Alberta Sustainable Resource Development < $<$ ttp://www.landuse.alberta.ca/Regional Plans/SouthSaskatchewan/Default.aspx>. 
that are based on staged development and therefore depend on the certainty of full project development prior to making significant initial investments. ${ }^{142}$

Furthermore, ALSA also fails to provide a date when regional plans are to become effective. If the government elects to make a regional plan effective immediately upon approval then there will most likely be delays in issuing regulatory approvals for proposed projects, as the applicable decision-making authorities will not only have to grapple with understanding the manner in which the regional plan necessitates a change to their policies, but attempt to create and apply new policies that are compliant with the regional plan.

\section{AMENDing AND EXTinguishing Rights}

ALSA provides that a regional plan may, "[f]or the purposes of achieving or maintaining an objective or a policy,” amend or extinguish a specific statutory consent or a type or class of statutory consents. ${ }^{143}$ This provision may cause oil, gas, and oil sands operators particular concern since the Framework specifically addresses the need to accelerate removal of industrial projects, particularly oil and gas projects, which adversely affect lands considered environmentally valuable. ${ }^{144}$

Section 11 of $A L S A$ provides that before a regional plan may include terms that specifically affect, amend, or extinguish a particular statutory consent or class of statutory consents, the Stewardship Minister must "provide an opportunity for the consent holder to propose an alternative means or measures of achieving or maintaining” the applicable policy or objective without the proposed effect, amendment, or extinguishment. ${ }^{145}$ This approach is similar to the inquiry process of the LCB. ${ }^{146}$ However, there are several important issues to be aware of regarding this alternative proposal concept.

In Petro-Canada: Applications for Eleven Well Licences, One Multiwell Gas Battery Licence, and Two Pipeline Licences - Sullivan Field, ERCB Decision 2010-022 (8 June 2010), the interveners requested that the ERCB “defer its decision on the proposed Project until the objectives and strategies of the South Saskatchewan Regional Plan were clarified.” The Board rejected this request, stating at 9.1:

In Decision 2008-029, the Board stated:

The Board notes that it is required to rule upon the Petro-Canada applications within the framework of current legislation and regulations until such time as the provincial government provides the Board with a revised mandate. If, prior to the Board's final decision, the provincial government implements the Policy with specific changes to the ERCB's mandate for the area of application, the Board will take all necessary steps to ensure that such changes are respected.

To date, the Board has not received any such indications that its mandate has changed. As such, the Board will proceed within the framework of current legislation and regulations.

Consequently, the Board has taken the approach that ALSA only alters its mandate upon the regional plans coming into effect. This approach, although sensible from a legislative interpretation perspective, should provide little comfort to licensees that projects approved by the Board during this interim period will not be subject to future restrictions once the applicable regional plan becomes effective. Supra note 6, s. 11(1)

Framework, supra note 4 at 34.

Supra note 6, s. 11(2).

The LCB is a provincial quasi-judicial agency established under the Expropriation Act, R.S.A. 2000, c. E-13, s. 25, to carry out duties under that Act and its regulations, including: determining whether expropriation should proceed when there is an objection (conducted under an inquiry process, and determining compensation payable to landowners and tenants where land has been expropriated by an authority and the affected parties cannot agree on the compensation. 
First, unlike the Expropriation $A c t,{ }^{147}$ which creates the procedural framework for the LCB inquiry process, $A L S A$ provides that the regional plan may establish the negotiation process in which the consent holder is permitted "to propose an alternative means" or measure. ${ }^{148}$ The use of "may" means that the government is not obligated to create such a process in each regional plan. However, without such a process there may be considerable uncertainty as to how proposals can be brought before the Minister. Further, by having the procedural components for this process included in the regional plans, rather than having them in $A L S A$ or in a related regulation, there exists the potential that separate processes, with separate rules and requirements, will be developed for different regions.

\section{A. COMPENSATION FOR LOSS OF VALUE OR USE OF LAND}

An important question is what happens if, as a result of $A L S A$ or a regional plan, a person loses their interest in land or the value of their interest is reduced. Section 19 of ALSA attempts to address this by providing:

No person has a right to compensation by reason of this Act, a regulation under this Act, a regional plan or anything done in or under a regional plan except either

(a) as expressly provided for under Part 3, Division 3, or

(b) as provided for under another enactment. ${ }^{149}$

This section gives rise to two distinct issues: first, what compensation is provided under ALSA; and second, what compensation is provided under other enactments.

\section{COMPENSATION UNDER ALSA}

Part 3, Division 3 of $A L S A$ provides for the compensation that title holders are entitled to as a result of land becoming subject to a conservation directive. ${ }^{150}$ As previously explained, the definition of title holder is restrictive and, importantly, excludes from its scope interests granted under the MMA. The effect of this restrictive definition appears to be that a freehold mineral or surface owner is entitled to compensation, as is a lessee under a freehold mineral lease (provided it has duly registered its interest), and as is a lessee under a private or Crown land surface lease (provided it has duly registered its interest). However, a lessee under a Crown mineral disposition is not entitled to compensation under this provision of ALSA. ${ }^{151}$ Interestingly, the definition of title holder may be broad enough to enable a registered royalty interest holder to receive compensation under ALSA if the royalty lands become subject to a conservation directive. ${ }^{152}$ Also, as a result of this definition, a party having a registered

147 Ibid.

148 Supra note 6, s. 11(2)(b).

149 Ibid.

$150 \quad$ Ibid., s. 36.

151 See ibid., s. 2(gg).

This would only apply to royalty interests on freehold lands, since an overriding royalty is not registerable under the $M M A$, supra note 40 , and thus would not fit within the definition of title holder under ALSA, ibid. 
interest in connection with a Crown mineral disposition (for example, a builders' lien) would likely be entitled to compensation.

As a result of this definition, two industry operators equally affected by a conservation directive, one being a freehold mineral lessee and one being a Crown mineral lessee, will be treated differently for the purposes of compensation. The government may have made this significant distinction to avoid sizable compensation liabilities. This unduly transfers considerable risk onto those operators that do business with the Crown rather than freehold mineral owners. As ALSA does not prohibit the creation of conservation directives after the initial approval of a regional plan, a perpetual risk exists that a Crown mineral interest may become subject to a future conservation directive.

Despite the foregoing, there are nonetheless significant compensation liabilities that the Crown may incur as a result of creating a conservation directive, particularly if a conservation directive impacts lands with freehold mineral interests. In such situations the adversely impacted parties may include surface lessors and lessees, mineral lessors and lessees, overriding royalty owners, and any other party with a registered interest (including registered security interests). ${ }^{153}$ The compensation that may be owed to a freehold lessor and lessee for the lost market value could undoubtedly be significant.

\section{COMPENSATION UNDER OTHER ENACTMENTS}

The use of "person” in s. 19 of ALSA rather than "title holder" expressly expands the right to compensation to any person, rather than just those that fit within the narrow definition of a title holder. Consequently, a person whose interest in land has been impacted by a conservation directive, and who is not entitled to compensation under $A L S A$ or a regional plan, may nonetheless be eligible for compensation if such a right to compensation exists under another provincial enactment. Importantly, for the petroleum industry, this provision may open the door to compensation for an operator who is unable to conduct anticipated field activities or is unable to conduct them in the manner they initially anticipated as a result of a regional plan. For instance, an operator may be unable to drill a well as a result of a regional plan designating the surface land for conflicting land use activities, such as tourism or conservation.

The Alberta Expropriation Act establishes an expropriation compensation process when such a process is not established in the enactment authorizing the expropriation. The Act defines "expropriation" as "the taking of land without the consent of the owner by an expropriating authority in the exercise of its statutory powers." 154 An "expropriating authority" is defined as "the Crown or any person empowered to acquire land by expropriation." "Ow5 "Owner” is defined broadly in the Act, but importantly does not include a carve-out for interests derived from Crown mineral dispositions. ${ }^{156}$ "Land” is defined as

Compensation of security interests in expropriated land is a concept currently existing and applied in Alberta: see the Expropriation Act, supra note 146, s. 49.

Ibid., s. 1(g) [emphasis added].

Ibid., s. 1(f).

Ibid., s. 1(k). 
"land as defined in the authorizing Act and if not so defined, means any estate or interest in land." ${ }^{157}$

Expropriation is generally thought of as involving an absolute transfer of title, such as the acquisition of land for the purposes of constructing a road or facilitating the construction of public works. An absolute taking of title to land is unlikely to occur as a result of ALSA. However, a restriction on the use of land may occur as a consequence of a regional plan. While the principle that expropriation can involve something less than the absolute taking of title (referred to as a "de facto expropriation") is fairly settled law in Canada, the application of this principle is particularly sensitive to the facts involved. It is beyond the scope of this article to fully explore this body of jurisprudence. Nevertheless, it is of value to review certain key decisions that support the proposition that certain land restrictions resulting from $A L S A$ and a regional plan could be considered expropriation, thereby entitling affected parties to seek compensation under the Expropriation Act.

In determining what constitutes "a de facto expropriation," the Alberta Court of Appeal in Alberta (Minister of Infrastructure) v. Nilsson held:

Expropriation generally involves an absolute transfer of title. However, some cases have held that something less than an absolute taking may amount to de facto expropriation. In such cases, while title nominally rested with the original owner, the degree of interference with the owner's property rights mandated compensation for loss of the property. 158

Furthermore, there are several compelling cases that have decided in favour of parties holding Crown mineral grants who were unable to exploit the grant due to subsequent regulatory restrictions.

In the Supreme Court of Canada decision of $R$. v. Tener, ${ }^{159}$ the claimants were the owners of mineral claims on lands that subsequently came to be located within a provincial park. The conditions governing the exploitation of a natural resource in the park became more onerous and, for several years prior to the action, the claimants were denied the park use permit necessary to explore or work the claims. The claimants were finally advised that no new exploration or development work would be permitted under park policy.

Justice Estey, writing for the majority, held that the right to exploit minerals constituted "property" and the denial of access to do the same amounted to a "taking."160 The Court further considered the question of whether a regulation that did not purport to physically acquire the plaintiff's property could constitute a taking. In answering this question in the affirmative, Estey J. held that

[t]he imposition of zoning regulation and the regulation of activities on lands, fire regulation limits and so on, add nothing to the value of public property. Here the government wished, for obvious reasons, to preserve the qualities perceived as being desirable for public parks, and saw the mineral operations of the respondents

Ibid., s. 1(h).

2002 ABCA 283, 320 A.R. 88 at para. 48.

[1985] 1 S.C.R. 533.

Ibid. at para. 59. 
under their 1937 grant as a threat to the park. The notice of 1978 took value from the respondents and added value to the park. The taker, the government of the province, clearly did so in exercise of its valid authority to govern. It clearly enhanced the value of its asset, the park. The respondents are left with only the hope of some future reversal of park policy and the burden of paying taxes on their minerals. The notice of 1978 was an expropriation and, in my view, the rest is part of the compensation assessment process. ${ }^{161}$

A similar decision was reached in Casamiro Resource Corp. v. British Columbia (A.G.), ${ }^{162}$ where the plaintiff held Crown mineral rights in a provincial park. In 1988, pursuant to the British Columbia Park Act ${ }^{163}$ no mineral exploration was permitted in a provincial park without a resource use permit. The province then passed an Order in Council prohibiting the issuance of resource use permits for that portion of the park where the plaintiff's mineral claims were located. The plaintiffs obtained a declaration from the Court that this was an expropriation and, as such, the plaintiffs were entitled to compensation.

The British Columbia Court of Appeal explained that " $\mathrm{t}]$ he diminution of rights does not always amount to a taking which, as a matter of law, is equivalent to expropriation." 164 In the end however, the Court held that the province's action amounted to an expropriation, noting that the legislative acts had turned the grants into "meaningless pieces of paper." "65

More recently, in Rock Resources Inc. v. British Columbia ${ }^{166}$ the Province of British Columbia enacted amending legislation that created a number of new provincial parks, the effect of which prevented the plaintiff from exploring for or developing minerals in parts of its mineral claims. The province argued that no taking had occurred because the plaintiff only held a contingent interest, which permitted exploration subject to statutory provisions that required the holder to seek approval from the province prior to exploring or developing his or her claim. ${ }^{167}$ Chief Justice Finch, writing for the majority, rejected this argument, holding in part that

[w] hatever the nature and scope of the rights the plaintiff held under the two mineral claims affected by the Park Amendment Act, 1995, those rights were recognized in the mining industry as having value.

It may well be, as the defendant contends, that mineral titles held under the Mineral Tenure Act (1988) could only be exploited or developed with prior authorization of the Lieutenant Governor in Council. However, the contingent nature of rights held under that Act does not mean that such rights were without any value.... The evidence of the marketplace, and of the defendant's legislation, and extra legislative schemes for compensation, render this argument hollow. ${ }^{168}$ 
Pursuant to this body of analysis, it would appear that the courts may be accepting of the position that a regional plan that significantly impairs a lessee's ability to exercise its rights has resulted in an expropriation of the lessee's interests. It is, however, crucial to this analysis to recognize that the right to compensation as a result of expropriation is not an inherent right in Canada (as it is in the U.S. and Australia). The courts have routinely affirmed that the Crown can expropriate private property without compensation if its legislative intention is clearly expressed, or as the principle is colourfully stated in Florence Mining Co., Limited v. Cobalt Lake Mining Co., Limited, “[t]he prohibition, 'Thou shalt not steal,' has no legal force upon the sovereign body."169 No such express wording is present in $A L S A$. In fact, s. 19 expressly provides that parties may have the right to compensation as a result of $A L S A$, its regulations, or a regional plan. ${ }^{170}$ Nonetheless, if the government is faced with significant compensation claims it may amend this section to exclude such avenues of compensation.

\section{HOW THE ALBERTA LAND STEWARDSHIP ACT May Change The Mineral ACQUisition Process}

\section{A. FREEHOLD DISPOSITIONS}

There is currently no regulatory review process that needs to be undertaken prior to a freehold mineral owner entering into a mineral or surface lease in connection with an oil and gas activity. ALSA applies to public and private lands, and therefore governs both types of arrangements, although the government has not indicated that it is considering creating a review process for freehold dispositions. Nonetheless, the various regulatory permits, licences, and consents required to conduct oil and gas activities will be subject to ALSA. Consequently, a prudent freehold lessee should, prior to entering into any such lease, determine if it is likely that its intended plans are consistent with the governing regional plan.

\section{B. Crown Dispositions}

A key concern identified by some stakeholders in the pre-Framework consultation process was the manner in which the Crown mineral disposition process is conducted without the public being given any opportunity to participate.

As background, the MMA grants the Minister broad discretion regarding the manner in which they may dispose of Crown mineral interests, generally providing that "the Minister may issue an agreement in respect of a mineral ... if the Minister considers the issuance of the agreement warranted in the circumstances.” ${ }^{171}$ In practice, however, the Minister refers requests for mineral dispositions to the Crown Mineral Disposition Review Committee (CMDRC), which is an interdepartmental committee ${ }^{172}$ that reviews proposed mineral dispositions to identify major surface or environmental concerns that may affect surface

(1909), 18 O.L.R. 275 at 279 (C.A.), cited in Authorson v. Canada (A.G.), 2003 SCC 39, [2003] 2 S.C.R. 40 at para. 53.

170 Supra note 6. See Part V.A, above, for a discussion of the possible avenues of compensation permitted under $A L S A$.

MMA, supra note 40 , s. 16.

172 Comprised of the ERCB, AENV, SRD, the Ministry of Culture \& Community Spirit, and the Special Areas Board. 
access for mineral exploration and development, such as important wildlife habitat. Based on the information received from the CMDRC, the Minister then determines if the requested mineral rights will be posted for disposition.

Although some industry operators may find the notion of opening this process up to stakeholder and public participation unappealing, this may become a reality under ALSA. Indeed, the government recently conducted a public survey seeking input on how to better integrate surface considerations into the Crown mineral disposition process, and stakeholder input is sought in other jurisdictions.

In British Columbia, the review process prior to the posting of mineral lands invites provincial agencies, local governments, First Nations, environmental organizations, and the general public to identify access constraints and land use conflicts for the lands to be posted. The responsible minister then decides whether to post the lands, and if so, under what conditions. At times comments received in the review process are included as part of the tenure document.

In the Yukon Territory, requests for postings of Crown oil and gas rights are subject to a review process in which the public, First Nations, and government agencies may make submissions in respect of environmental, socio-economic, and surface access concerns. Based on the submissions from the review, the Ministry makes a determination as to whether to make available the proposed lands for the public bidding process.

Adopting a system similar to that used in British Columbia or the Yukon in Alberta would provide an opportunity for stakeholders to express concerns with proposed dispositions, which should help reduce land use conflicts, and provide greater certainty to lessees that the mineral rights they acquire will be rights that they can develop.

\section{HOW THE ALBERTA LAND STEWARDSHIP ACT May Change Regulatory Approvals}

\section{A. THE EnERgy Resources CONSERVATION BOARD}

When reviewing an application for a proposed energy project, the ERCB is required to consider whether the proposed project is in "the public interest"; a determination to be based on a consideration of the social, economic, and environmental effects of a proposed project. ${ }^{173}$ As a result of $A L S A$, the ERCB will now have to expand the scope of its considerations to also contemplate whether the proposed project conforms with the applicable regional plan. This will presumably require the ERCB to consider the vision, goals, and objectives established in the regional plan, determine whether the incremental cumulative environmental effects of the proposed project will exceed environmental thresholds, and balance trade-offs between the proposed activity and competing land uses. Each of these concepts are more easily understood in the abstract than in the reality of a specific activity. This may be a challenging task for the Board and may result in longer processing times for project applications. 
In attempting to apply each of the new considerations, the Board will have to address a number of significant issues, including how to consider competing land uses, how to consider cumulative impacts, whether to expand its test for standing, and whether it will be responsible for considering conservation and stewardship actions.

\section{WILL THE BOARD ASSUME RESPONSIBILITY FOR CONSIDERING COMPETING LAND USES?}

The Board will need to determine whether it will assume responsibility for addressing conflicting land use issues in at least three separate project proposal scenarios: those involving Crown minerals, those on private mineral or surface lands, and those on public surface lands.

If the Crown mineral disposition was granted after the approval of the governing regional plan, the ERCB might determine that responsibility for considering conflicting land uses is the responsibility of the Minister, under the $M M A$, as one might expect that the CMDRC should be reviewing consistency with regional plans. If the mineral disposition was granted prior to the approval of the regional plan the ERCB, as possibly the first authority with the opportunity to consider the regional plan in connection with such disposition, may determine that it should be responsible to consider competing land uses. Alternatively, it may determine that the Minister, under the MMA, has the responsibility to review all previously granted mineral dispositions to determine their compliance with the regional plans.

In the second scenario, the ERCB may be the first regulatory authority to consider the applicability of the regional plan to the freehold lands in question. ${ }^{174}$ It is therefore likely that the ERCB will have to assume responsibility for considering land use conflicts.

As for the third scenario, since the management of public lands is within the mandate of SRD, and as ALSA has amended the PLA to require that SRD only grant surface authorizations in compliance with the regional plans, ${ }^{175}$ it is likely that the ERCB will not need to assume responsibility for consideration of competing land uses that relate to public surface lands. Where the Board determines that SRD is responsible for considering potential land use conflicts, there may now be an increased chance that parties opposed to developments will object to the associated surface authorization application pursuant to the new review and appeal mechanisms created in the PLA and the Forests Act by ALSA. ${ }^{176}$ This may result in further regulatory hurdles that will need to be overcome by project proponents. person, or if the proposed activity does not relate to a mineral interest, then surface access issues are addressed by the Surface Rights Board after the ERCB has granted the licence, permit, or approval. PLA, supra note 40, s. 11(2).

176 The appeal mechanisms are provided for in Part 7 of the PLA, ibid., and Part 5 of the Forests Act, supra note 40 . 


\section{HOW WiLl THE BOARD CONSIDER CUMULATIVE ENVIRONMENTAL EFFECTS?}

The ERCB already expressly considers cumulative effects for major projects. However, the regional plans may require the Board to expressly consider cumulative effects for smaller projects (such as an individual well or battery application). This may require project proponents to include an analysis of the cumulative effects of their project in their application.

\section{Will the “Directly AfFeCteD” Test BE EXPANDED?}

The Board's governing legislation provides that if a proposed project may "directly and adversely affect the rights of a person," such person is granted the right to request a public hearing in which such person is permitted to participate. ${ }^{177}$ The Board has determined that a person must satisfy a two-part test (of mixed law and fact) in order to meet this standard. ${ }^{178}$ This test has faced frequent criticism by some stakeholders who do not satisfy it but nonetheless feel that they have a sufficient connection to the proposed project that they should be given the opportunity to participate in the application process. The Board has largely resisted these criticisms and the Alberta Court of Appeal has given broad deference to the Board's discretion on this matter. However, due to the expanded scope of factors that the Board is required to consider as a result of $A L S A$, a larger number of people may be directly affected by a project, and thus eligible to participate in the process.

\section{RESPONSIBILITY FOR CONSERVATION AND STEWARDSHIP TOOLS?}

As described above, ALSA establishes the framework for market-based, tradeable conservation, and stewardship tools. The Framework contemplates that project proponents should be able to use these tools to counterbalance the environmental impacts of their project. ${ }^{179}$ No regulations have yet been passed and therefore it is not yet known which regulatory authority or authorities will be responsible for evaluating the use of these tools and what the ERCB's role will be in determining the requirement for, or effectiveness of, counterbalancing.

The government has consistently stated that the purpose of ALSA is not to unnecessarily reorganize the existing regulatory system. It is therefore reasonable to assume that the ERCB will continue as the primary energy project regulator in the province, and therefore will become responsible for weighing the value of conservation offsets or stewardship units in connection with project proposals. It is not clear how the Board would address this, and it may have to weigh the relative significance of project disturbances against the counterbalancing activities (for use of conservation offsets) or determine the unit value equivalent of disturbances (for use of stewardship units). Since ALSA contemplates that these tools are to be market-based, the inexact science of environmental evaluation may impose

ERCA, supra note 40, s. 26(2); ERCB, Directive 029: Energy and Utility Development Applications and the Hearing Process (Calgary: ERCB, 2003).

This test has been routinely upheld by the Alberta Court of Appeal: see e.g. Sawyer v. Alberta (Energy and Utilities Board), 2007 ABCA 297, 422 A.R. 107 at para. 18.

Framework, supra note 4 at 33-34. 
upon the Board a new level of environmental and market-based scrutiny. Alternatively, this responsibility may fall to AENV, as it has experience with wetland replacement practices and conservation easements. However, since AENV's mandate for environmental reviews does not encompass all energy projects, this remains to be seen.

It is also unknown how the ERCB will enforce the conservation offset commitments of project proponents. For instance, will Board approvals be subject to satisfactory performance of conservation offsets? If so, what sanctions will the ERCB impose if the conservation offsets are not completed within the timeframe or in the manner committed to by the project proponent? Again, because these instruments are to be market-based, it is crucial to the integrity of the system that a monitoring program be implemented to ensure that offset commitments are correctly completed.

\section{B. Alberta EnVIRONMENT}

ALSA has also modified AENV's governing legislation so that it is now required to take action in accordance with regional plans. ${ }^{180}$ Consequently, AENV will also face the challenge of integrating regional plans into its existing approval processes. This will likely necessitate revisions to the Code of Practice for Exploration Operations ${ }^{181}$ and the Code of Practice for Energy Recovery, ${ }^{182}$ among others, which have been developed to replace the approval requirements for certain oil and gas developments. Finally, as with the ERCB, AENV may also find that more parties have standing to participate in its approval process.

\section{RETROACTIVITY}

A potentially significant issue with $A L S A$ is how existing developments will be integrated into the new land use regime. Other than the opportunity to propose alternatives to amend or extinguish existing statutory rights, and a vague reference that regional plans may "provide for transitional or bridging arrangements," 183 ALSA provides minimal guidance as to how existing land use activities that are not consistent with the regional plans are to be addressed.

This issue affects two broad categories of existing oil and gas developments: developments located in areas prioritized for conservation activities, and developments where continued operations will result in environmental impacts exceeding the environmental thresholds identified in a regional plan. For the first category, as much of the province is subject to some degree of oil and gas development it is likely that areas identified in a regional plan for conservation, tourism, and/or recreational activities may experience conflict between these objectives and existing industrial activity. In the Framework, the government indicated that it was considering initiatives to expedite the removal of industrial and oil and

Alberta Environment, Code of Practice For Exploration Operations (made under the Environmental Protection and Enhancement Act) (Edmonton: Queen's Printer, 2005), online: Queen’s Printer < http:// www.qp.alberta.ca/documents/codes/EXPLORE.pdf>.

Government of Alberta, Environmental Code of Practice for Energy Recovery (made under the Environmental Protection and Enhancement Act) (Edmonton: Queen's Printer, 2005), online: Queen's Printer <http://www.qp.alberta.ca/documents/codes/ENERGY.PDF>.

ALSA, supra note 6, s. 9(2)(l). 
gas activities from such areas, ${ }^{184}$ but little guidance was offered as to what these initiatives may include other than lease-swapping arrangements. While potentially reasonable for undeveloped leases, the case may not be the same for developed leases where establishing value equalization may be a difficult task.

Although the second category may appear to consist of a limited group of projects, it may prove to be fairly significant. For instance, there is considerable concern that fragmentation of the boreal forest by access roads, utility right-of-ways, pipeline right-of-ways, and seismic cut-lines is having an adverse effect on that area's biodiversity.

\section{ConCLuSion}

ALSA marshals in a new era of land use management in Alberta. An era in which virtually all land use activities on both public and private lands in the province will be regulated based on regional level considerations. Since no regional plans are yet approved it still largely remains to be seen how sweeping the changes will be as a result of ALSA, but based on the content in the Framework there is good reason to believe that they may be significant. Economic activities are to be balanced against environmental and social considerations (with at least 16 percent of the Lower Athabasca planning region to be excluded from development), there are strong indications that existing and future developments (particularly oil, gas, and oil sands developments) will be subject to counterbalancing activities, and the government is openly contemplating the swapping, amendment, or cancellation of leases to achieve its conservation goals.

Importantly, $A L S A$ does not provide means to seek review or amendment of the regional plans and once a plan is approved the government is not required to review it for ten years. ${ }^{185}$ Consequently, involvement in the public consultation process that may be offered by the RACs will be crucial so as to ensure that the regional plans are developed with an accurate understanding of the potential adverse implications they may impose on existing and future oil and gas activities in the province. 